\title{
Antibacterial activity of plasma from crocodile (Crocodylus siamensis) against pathogenic bacteria
}

Jintana Kommanee ${ }^{1}$, Sutthidech Preecharram², Sakda Daduang ${ }^{1}$, Yosapong Temsiripong ${ }^{3}$, Apisak Dhiravisit ${ }^{4}$, Yuzo Yamada ${ }^{5,6,7}$ and Sompong Thammasirirak ${ }^{*}$

\begin{abstract}
Background: The Siamese crocodile (Crocodylus siamensis) is a critically endangered species of freshwater crocodiles. Crocodilians live with opportunistic bacterial infection but normally suffer no adverse effects. They are not totally immune to microbial infection, but their resistance thereto is remarkably effective. In this study, crude and purified plasma extracted from the Siamese crocodile were examined for antibacterial activity against clinically isolated, human pathogenic bacterial strains and the related reference strains.
\end{abstract}

Methods: Crude plasma was prepared from whole blood of the Siamese crocodile by differential sedimentation. The crude plasma was examined for antibacterial activity by the liquid growth inhibition assay. The scanning electron microscopy was performed to confirm the effect of crude crocodile plasma on the cells of Salmonella typhi ATCC 11778. Effect of crude crocodile plasma on cell viability was tested by MTT assay. In addition, the plasma was purified by anion exchange column chromatography with DEAE-Toyopearl $650 \mathrm{M}$ and the purified plasma was tested for antibacterial activity.

Results: Crude plasma was prepared from whole blood of the Siamese crocodile and exhibited substantial antibacterial activities of more than $40 \%$ growth inhibition against the six reference strains of Staphylococcus aureus, Salmonella typhi, Escherichia coli, Vibrio cholerae, Pseudomonas aeruginosa, and Staphylococcus epidermidis, and the four clinical isolates of Staphylococcus epidermidis, Pseudomonas aeruginosa, Salmonella typhi, and Vibrio cholerae. Especially, more than $80 \%$ growth inhibition was found in the reference strains of Salmonella typhi, Vibrio cholerae, and Staphylococcus epidermidis and in the clinical isolates of Salmonella typhi and Vibrio cholerae. The effect of the crude plasma on bacterial cells of Salmonella typhi, a certain antibacterial material probably penetrates progressively into the cytoplasmic space, perturbing and damaging bacterial membranes. The effect of the crude plasma was not toxic by the yellow tetrazolium bromide (MTT) assay using a macrophage-like cell, RAW 264.7. The pooled four fractions, designated as fractions D1-D4, were obtained by column chromatography, and only fraction D1 showed growth inhibition in the reference strains and the clinical, human pathogenic isolates.

Conclusions: The crude and purified plasma from the Siamese crocodile significantly showed antibacterial activity against pathogenic bacteria and reference strains by damage cell membrane of target bacterial cells. From the MTT assay, the Siamese crocodile plasma was not cytotoxic to the cells.

Keywords: Crocodile (Crocodylus siamensis), Antibacterial activity, Pathogenic bacteria, Cytotoxicity

\footnotetext{
*Correspondence: somkly@kku.ac.th

${ }^{1}$ Department of Biochemistry, Faculty of Science, Protein Proteomic Research

Group, Khon Kaen University, Khon Kaen 40002, Thailand

Full list of author information is available at the end of the article
} 


\section{Background}

The powerful antibiotic was first discovered in 1940s [1], many of which originate from natural sources. Meanwhile, microbes resistant to these antibiotics continuously emerge over time and spread all over the world. This situation motivated scientists to search for new naturally occurring bacterial agents that may be potential antibiotics. Reptiles including alligators and crocodiles were subjected to an exploration of the antibiotic properties from their body.

Bacteria and fungi coexist with other living organisms. Despite such an ecological phenomenon, pathogenic microbial invasion into hosts does not normally take place, as the host has the defense mechanisms that counteract infection. One of such systems is based on non-specific immunity, which comprises a wide variety of peptides [2] and factors [3] with potent antimicrobial properties.

A kind of crocodiles (Crocodylus siamensis), the Siamese crocodile is a critically endangered species of freshwater crocodiles, originally distributed in most of South East Asia. Crocodilians live with opportunistic bacterial infection but normally suffer no adverse effects. They are not totally immune to microbial infection, but their resistance thereto is remarkably effective. The immune system of crocodilians has not been well characterized, but there are several reports that describe the antimicrobial efficacy of alligator serum towards bacteria, viruses, and amoeba [4-6]. Merchant et al. [5] recently proposed that the complement systems of alligators are effective in killing bacteria. More recently, leukocyte extract of the American alligator (Alligator mississippiensis) showed a broad spectrum of antibiotic properties on bacteria, fungi, and viruses $[7,8]$. Effects of bacterial lipopolysaccharide on peripheral leukocytes were also investigated in the American alligator [9].

In the present study, we have examined the crude and purified plasma obtained from the Siamese crocodile for the antibacterial activity against clinically isolated, human pathogenic bacterial strains and the related reference strains, which will be of great importance in medical industry.

\section{Materials and methods \\ Plasma samples}

Crocodiles (Crocodylus siamensis) were captured and housed at the local Sriracha Moda Farm, Chon Buri, Thailand. The crocodiles (age ranging from 1-3 years) were housed in a single tank, and treated with electric shock. Blood samples were collected from the dorsal vein using a heparinized $38 \mathrm{~mm}$ long 18 gauge needle and a $60 \mathrm{ml}$ syringe and transferred to heparinized vacuum tubes. The crocodile blood in heparinized vacuum tubes was kept at $4^{\circ} \mathrm{C}$ for overnight and then centrifuged $800 \mathrm{~g}$ to obtain crude plasma, which was kept at $-70^{\circ} \mathrm{C}$ until used $[1-3,7,10-16]$.

\section{Bacterial strains}

Staphylococcus aureus ATCC 25923, Salmonella typhi ATCC 11778, Escherichia coli O157:H7, Vibrio cholerae non01, Pseudomonas aeruginosa ATCC 27853, Staphylococcus epidermidis ATCC 12228, Staphylococcus epidermidis clinical isolate 1, Pseudomonas aeruginosa clinical isolate 1, Salmonella typhi clinical isolate 1, and Vibrio cholerae clinical isolate 1 were maintained in nutrient agar slants at $4^{\circ} \mathrm{C}$.

\section{Purification of plasma by DEAE}

After blood centrifugation for plasma collection, crude plasma $200 \mathrm{ml}$ was diluted with $18 \mathrm{ml}$ of $25 \mathrm{mM}$ sodium acetate buffer, $\mathrm{pH} 5.0$ and stirred for $10 \mathrm{~min}$ at room temperature. The homogenate was centrifuged at $12000 \mathrm{~g}$ for $15 \mathrm{~min}$. The supernatant was collected, stirred, and incubated with CM-Toyopearl $650 \mathrm{M}$ cation exchange resin. The incubated resin was packed on column and washed with $2 \mathrm{cv}$ of $25 \mathrm{mM}$ acetate buffer, $\mathrm{pH}$ 5.0. The un-absorbed protein fraction including washings was adjusted to $\mathrm{pH} 8.1$ and then loaded onto the DEAEToyopearl $650 \mathrm{M}$ anion exchange resin equilibrated with $25 \mathrm{mM}$ Tris- $\mathrm{HCl}, \mathrm{pH}$ 8.1. The absorbed fraction was eluted with stepwise $\mathrm{NaCl}$ concentration of $0.1,0.2,0.3$, 0.4 , and $0.5 \mathrm{M}$ at flow rate of $1.0 \mathrm{ml} / \mathrm{min}$. The eluted fraction was collected and monitored at A280 nm for determining the peak of protein.

\section{Assay of antibacterial activity}

The antimicrobial activity of the crude plasma preparation was evaluated against the four pathogens and six reference strains. The antibacterial activity was measured by the disc diffusion method [17] with modifications. The inoculation of each bacterium was done by placing inoculum $10^{7} \mathrm{CFU} / \mathrm{ml}$ on Mueller-Hinton agar (Scharlau, Spain). After drying the agar for 3 to $5 \mathrm{~min}, 6 \mathrm{~mm}$ discs were applied to each plate, and the DEAE eluate fractions (25 $\mathrm{\mu l}$; concentration, $1 \mathrm{mg} / \mathrm{ml}$ ) was pipetted onto each disc. The agar plates were incubated at $37^{\circ} \mathrm{C}$ for $18 \mathrm{~h}$. Clear zone diameter was measured with a ruler at the back of the plate. Deionized distilled water (DDW) and streptomycin $10 \mu \mathrm{g}$ on discs were used respectively as negative and positive control assays.

The DEAE eluate fractions were assayed for antibacterial activity against the ten test strains mentioned above by a liquid growth inhibition assay [18]. DDW and streptomycin $3 \mu \mathrm{g}$ were used respectively as negative and positive controls. The antimicrobial activity tests were done in triplicate to obtain valid statistical evaluation of the results, which were expressed as mean \pm S.D. The percentage of the growth inhibition was calculated 
with absorbance values using the following equation, CI $(\%)=(\mathrm{A}-\mathrm{B}) / \mathrm{A} \times 100$, where $\mathrm{CI}$ is the percentage inhibition index, $A$ is the value observed at $A 550 \mathrm{~nm}$ of bacteria for negative control, and $B$ is the value observed at A550 nm of bacteria for a plasma eluate or streptomycin.

\section{Scanning electron microscopy}

The scanning electron microscopy (SEM) was performed according to Lau et al. [19] with slight modifications. Salmonella typhi ATCC 11778 was grown in nutrient broth and harvested at the logarithmic phase of growth by centrifugation at $3,000 \mathrm{~g}$ for $5 \mathrm{~min}$. The bacterial cells were then washed twice with phosphate buffered saline (PBS), $\mathrm{pH} 7.0$ and re-suspended to the final concentration of $10^{6} \mathrm{CFU} / \mathrm{ml}$. Aliquots of suspension of Salmonella typhi ATCC $11778(100 \mu \mathrm{l})$ were individually incubated with the crude plasma $(300 \mu \mathrm{g} / 50 \mu \mathrm{l})$ at $37^{\circ} \mathrm{C}$ for $2 \mathrm{~h}$. The incubated bacterium $150 \mu \mathrm{l}$ was fixed with equal volumes of $2.5 \%$ glutaraldehyde (Sigma, USA) in $0.1 \mathrm{M}$ phosphate buffer, $\mathrm{pH} 7.2$ for $2 \mathrm{~h}$. The fixed cells were carefully pipetted and settled onto a $0.2 \mu \mathrm{m}$ polycarbonate membrane filter (Whatman, Germany) for five min and then washed twice with PBS, pH 7.0. The fixed material was dehydrated by rinsing for $15 \mathrm{~min}$ repeatedly with ethanol solutions, of which the concentration was elevated stepwise from $30 \%, 50 \%, 70 \%, 90 \%$, and finally $100 \%$ ethanol. The dehydrated material in the absolute ethanol was dried in a critical point drier (Critical point drier, Balzers model CPD 020) with carbon dioxide as the drying agent. The dry material was coated by sputter coater (Sputter Coater, Balzers model SCD 040) with gold palladium and examined by a scanning electron microscope (JEOL, model JSM-5410LV). The negative control was performed in a similar manner except that the bacterial cells were incubated with PBS, pH 7.0 instead of the crude crocodile plasma.

\section{Cell line}

The mouse macrophage cell line, RAW 264.7 was obtained from the European Collection of Cell Cultures (ECACC) and cultured in RPMI medium supplemented with $10 \%$ heat-inactivated fetal bovine serum (FBS), penicillin 100 units $/ \mathrm{ml}$, streptomycin $100 \mu \mathrm{g} / \mathrm{ml}$, and amphotericin B $25 \mu \mathrm{g} / \mathrm{ml}$ were maintained at $37^{\circ} \mathrm{C}$ in a $5 \% \mathrm{CO}_{2}$ humidified atmosphere $\left(\mathrm{CO}_{2}\right.$ incubator, Heal Force). The cells were treated with the crude plasma at different concentrations during $1 \mathrm{~h}$ for the indicated period.

\section{MTT assay for cell viability}

Cells were seeded at a density of 104 cells/well in 96-well plates overnight, followed by the treatment with different concentrations of the crude plasma, 62.5, 125, 250, 500, and $1,000 \mu \mathrm{g} / \mathrm{ml}$. The cell viability of RAW 264.7 was measured after $24 \mathrm{~h}$ exposure to the test plasma by colorimetric assay, based on the ability of mitochondria in viable cells to reduce MTT [3-(4,5-Dimethylthiazol-2-yl)2,5-diphenyltetrazolium bromide]. An aliquot of MTT solution $0.5 \mathrm{mg} / \mathrm{ml}$ was added to each well, and after $30 \mathrm{~min}$ incubation at $37^{\circ} \mathrm{C}$, the medium was discarded, and the formazan blue formed in the cells was dissolved in dimethyl sulfoxide (DMSO). Absorbance at $570 \mathrm{~nm}$ was determined with a microplate reader (Bio-Rad, Model 680, USA). The absorbance of the formazan formed in non-treated cells was taken as $100 \%$ viability.

\section{Statistical analysis}

Data points in all experiments were performed in triplicate to obtain valid statistical evaluation of the results. Each sample CFUs/ml was calculated by multiplying the number of colonies counted by the dilution factor. All results represented the means \pm S.E.M for at three determinations.

\section{Results}

\section{Antibacterial activity of crude crocodile plasma}

The undiluted crude Siamese crocodile plasma containing $114 \mathrm{mg}$ protein/ml determined by the Bradford assay (Bradford, 1976) was examined for antibacterial activity by the liquid growth inhibition assay. The crocodile plasma was effective as an antibacterial substance against the following six reference strains and four pathogenic isolates significantly: Staphylococcus aureus ATCC 25923, Salmonella typhi ATCC 11778, Escherichia coli O157:H7, Vibrio cholerae non01, Pseudomonas aeruginosa ATCC 27853, Streptococcus epidermidis ATCC 12228, Streptococcus epidermidis clinical isolates 1, Pseudomonas aeruginosa clinical isolate 1, Salmonella typhi clinical isolate 1, and Vibrio cholerae clinical isolate 1. The inhibition effects on the bacterial strains were mostly over $40 \%$ (Figure 1 ). Especially, the crocodile plasma showed high inhibition effects more than $80 \%$ on Salmonella typhi ATCC 11778 , Vibrio cholerae non01, Streptococcus epidermidis ATCC 12228, Pseudomonas aeruginosa clinical isolates 1 , and Salmonella typhi clinical isolates 1 . The experimental data obtained indicated that the crude Siamese crocodile plasma had antibacterial properties and bactericidal actions to some bacterial strains both gram-positive and gram-negative.

\section{Antibacterial action of crocodile plasma examined by scanning electron microscopy}

The effect of the crude crocodile plasma on the cell of Salmonella typhi ATCC 11778 tested as a reference strain was examined by SEM. As shown in Figure 2a, the untreated cells had smooth, intact cell surfaces. In contrast, crude plasma-induced breakage and roughness was shown in the 


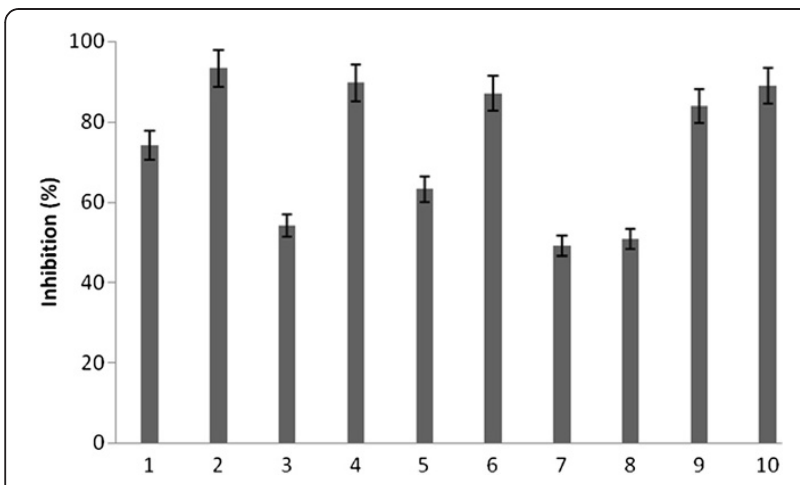

Figure 1 The antibacterial effect of the crude Siamese crocodile plasma on pathogenic bacteria. The final protein concentration of the crude plasma examined was $50 \mu \mathrm{g} / \mathrm{ml}$. 1, Staphylococcus aureus ATCC 25923; 2, Salmonella typhi ATCC 11778; 3, Esccherichia coli O157:H7; 4, Vibrio cholerae non01; 5, Pseudomonas aeruginosa ATCC 27853; 6, Streprococcus epidermidis ATCC 12228; 7, Streprococcus epidermidis clinical isolate $1 ; 8$, Pseudomonas aeruginosa clinical isolate $1 ; 9$, Salmonella typhi clinical isolate 1; 10, Vibrio cholerae clinical isolate 1. Bars represent the mean and the standard deviations performed in triplicate.

cell surfaces after a $120 \mathrm{~min}$ treatment (Figure 2b). The results obtained indicated that the cell surface including bacterial cell walls and/or cell membranes was an important target for action by the crocodile plasma.

\section{Effect of crude crocodile plasma on cell viability}

To assess the cytotoxicity of the crocodile plasma administered to the cells, macrophages RAW 264.7 was used. Although the MTT assay is an indirect measurement of cell density or the number of living cells attached to the culture plate by formation of colored formazan crystals, the crocodile plasma exhibited almost similar viability of more than $96 \%$ to that of non-treated cells, which was taken as $100 \%$ viability (Figure 3 ). The results obtained indicated that the crocodile plasma was not cytotoxic to the cells.

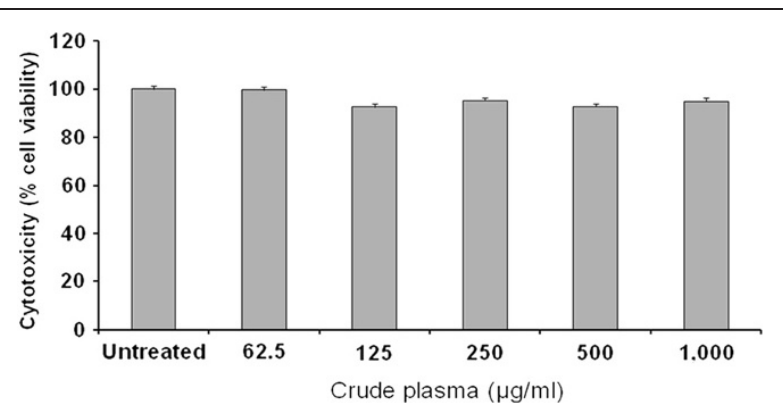

Figure 3 The effect of the crude Siamese crocodile plasma on a macrophage-like cell, RAW 264.7 determined by the MTT assay. The final protein concentration of the plasma tested was $1000 \mu \mathrm{g} / \mathrm{ml}$. The cell viability without crude plasma was taken as $100 \%$, where $\mathrm{n}=8$ (mean \pm S.E.M.).

Antibacterial activity of partially purified crocodile plasma The Siamese crocodile plasma was separated into four pooled fractions by anion exchange column chromatography with DEAE-Toyopearl $650 \mathrm{M}$, designated as fractions D1, D2, D3, and D4 (Figure 4). Fractions D1 and D2 were eluted at $0.1 \mathrm{M} \mathrm{NaCl}$ concentration, whereas fractions D3 and D4 were eluted respectively at 0.2 and $0.3 \mathrm{M} \mathrm{NaCl}$. All the fractions were assayed for antimicrobial activity.

In the disc diffusion assay that was made as a qualitative analysis, some of the four fractions exhibited antibacterial activities against all the tested ten pathogenic bacteria (Table 1). The most active fractions were found in fraction D1 in all the ten test strains. The activity of the other three fractions, D2, D3, and D4 was, however, calculated to be $50 \%$ or less of that of fraction D1.

In the liquid growth inhibition assay that was made as a quantitative analysis, clear results were obtained (Figure 5). In only fraction D1, significantly inhibited the growth of all tested bacteria, which almost corresponded to that of streptomycin $3 \mu \mathrm{g} / \mathrm{ml}$. Interesting is that the growth of both Salmonella typhi ATCC 11778 and clinical isolate 1 and Streptococcus epidermidis ATCC 1222 and clinical isolate 1 was not inhibited by streptomycin.
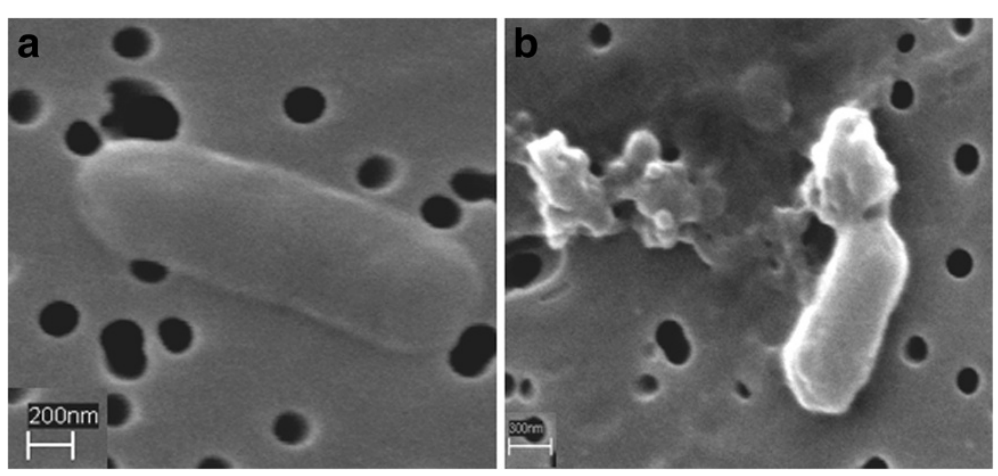

Figure 2 The antibacterial effect of the crude Siamese crocodile plasma on cells of Salmonella typhi ATCC 11778. The cells were incubated with the crude plasma for $120 \mathrm{~min}$ and observed by scanning electron microscopy. a, without incubation; b, with incubation. 


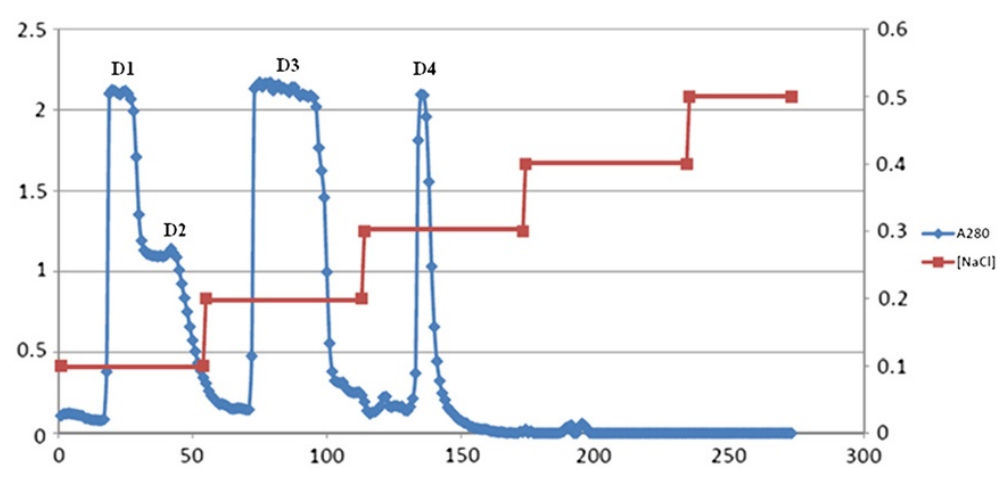

Figure 4 The DEAE chromatography of the crude Siamese crocodile plasma. The chromatography was made on a DEAE-Toyopearl $650 \mathrm{M}$ column. Fraction D1 contained fraction tube numbers 19-24, fraction D2 contained fraction tube numbers 27-72, fraction D3 contained fraction tube numbers 73-96, and fraction D4 contained fraction tube numbers 133-142. •, absorbance at $280 \mathrm{~nm}$; $\mathbf{\square}$, concentration of $\mathrm{NaCl}$.

\section{Discussion}

The antibacterial activity has been reported in the American alligator (Alligator mississippiensis), the saltwater crocodile (Crocodylus porosus), and the freshwater crocodile (Crocodylus johnstoni) [5,20]. However, only a few reports were found in one of the freshwater Siamese crocodiles [13]. In the present study, the Siamese crocodile plasma was effective as an antibacterial agent against the following six reference strains and the four pathogens both Gram-negative and Gram-positive species: Staphylococcus aureus ATCC 25923, Salmonella typhi ATCC 11778, Ecsherichia coli. coli O157:H7, Vibrio cholerae non01, Pseudomonas aeruginosa ATCC 27853, Streptococcus epidermidis ATCC 12228, Streptococcus epidermidis clinical isolate 1, Pseudomonas aeruginosa clinical isolate 1, Salmonella typhi clinical isolate 1, and Vibrio cholerae clinical isolate 1. All the bacterial species used in this study are known to be human pathogens. It is obvious that the Siamese crocodile plasma has a broad

Table 1 The antibacterial activity of the DEAE eluate fractions determined by the disc diffusion assay

\begin{tabular}{lllll}
\hline Bacterial strain & \multicolumn{4}{c}{ Inhibition zone (mm) of fraction* } \\
\cline { 2 - 5 } & D1 & D2 & D3 & D4 \\
\hline S. aureus ATCC 25923 & 9.6 & 2.4 & 2.5 & - \\
S. typhi ATCC 11778 & 12.4 & - & - & - \\
E. coli O157:H7 & 5.5 & 2.2 & 2.8 & - \\
V. cholerae non01 & 10.8 & 3.1 & - & - \\
P. aeruginosa ATCC 27853 & 6.7 & 2.5 & 1.8 & - \\
S. epidermidis ATCC 12228 & 14.2 & 1.8 & - & - \\
S. epidermidis clinical isolate 1 & 12.5 & 2.4 & 2.5 & - \\
P. aeruginosa clinical isolate 1 & 6.5 & 1.8 & 1.5 & - \\
S. typhi clinical isolate 1 & 11.8 & 2.8 & 2.2 & 1.3 \\
V. cholerae clinical isolate 1 & 9.7 & 2.6 & 2.0 & 1.4 \\
\hline
\end{tabular}

For the assay condition, see the text. -, no growth inhibition. *The values not include diameter of paper disc. band of spectrum in antibacterial activities. The results demonstrated that the antibacterial activities were highly effective as an antibacterial agent against both Grampositive and Gram-negative bacteria, consistent with the study in American alligator serum [6].

Antimicrobial peptides have been isolated from a broad variety of phylogenetically diverse organisms and separated into a variety of classes based on their chemical structures [21]. The classes of the peptides showed different kinds of mechanisms on antimicrobial action [13]. In the present study, the antibacterial mechanism of the crude Siamese crocodile plasma on the cell surface, including cell walls and membranes, of Salmonella typhi ATCC 11778, a reference strain was studied by SEM. The results obtained suggested that an antibacterial compound probably penetrates progressively into the cytoplasmic space, perturbing and damaging bacterial cell surface, as found in the previous report of Preecharram et al. [13], who isolated an antibacterial compound called crocosin from the Crocodylus siamensis plasma using RP-HPLC and found that the compound exhibited an antibacterial activity toward Salmonella typhi and Staphylococcus aureus. These results in the actions of the antimicrobial compounds correspond with the actions of the antimicrobial peptides such as bactenecin 5 , bactenecin 7, poly-L-lysine, cecropin B, LL-37 PGYa, melittin, Hecate-1 and SMAP-29 [11,12,14,22-24]. Most antibacterial peptides found thus far, such as those from amphibian skin, magaingnin and dermaseptin are known to exert their antimicrobial activity by permeabilizing the membrane $[11,23]$. The antibacterial compound isolated by Preecharram et al. [13] has a similar mechanism on action to those of the antibacterial peptides reported $[14,22]$ in disrupting the cell surface. However, all antimicrobial peptides have several factors, in common, which are able to interact with the negatively charged phospholipids in the membranes of microbes and are also amphipathic, so that the compounds interact with 

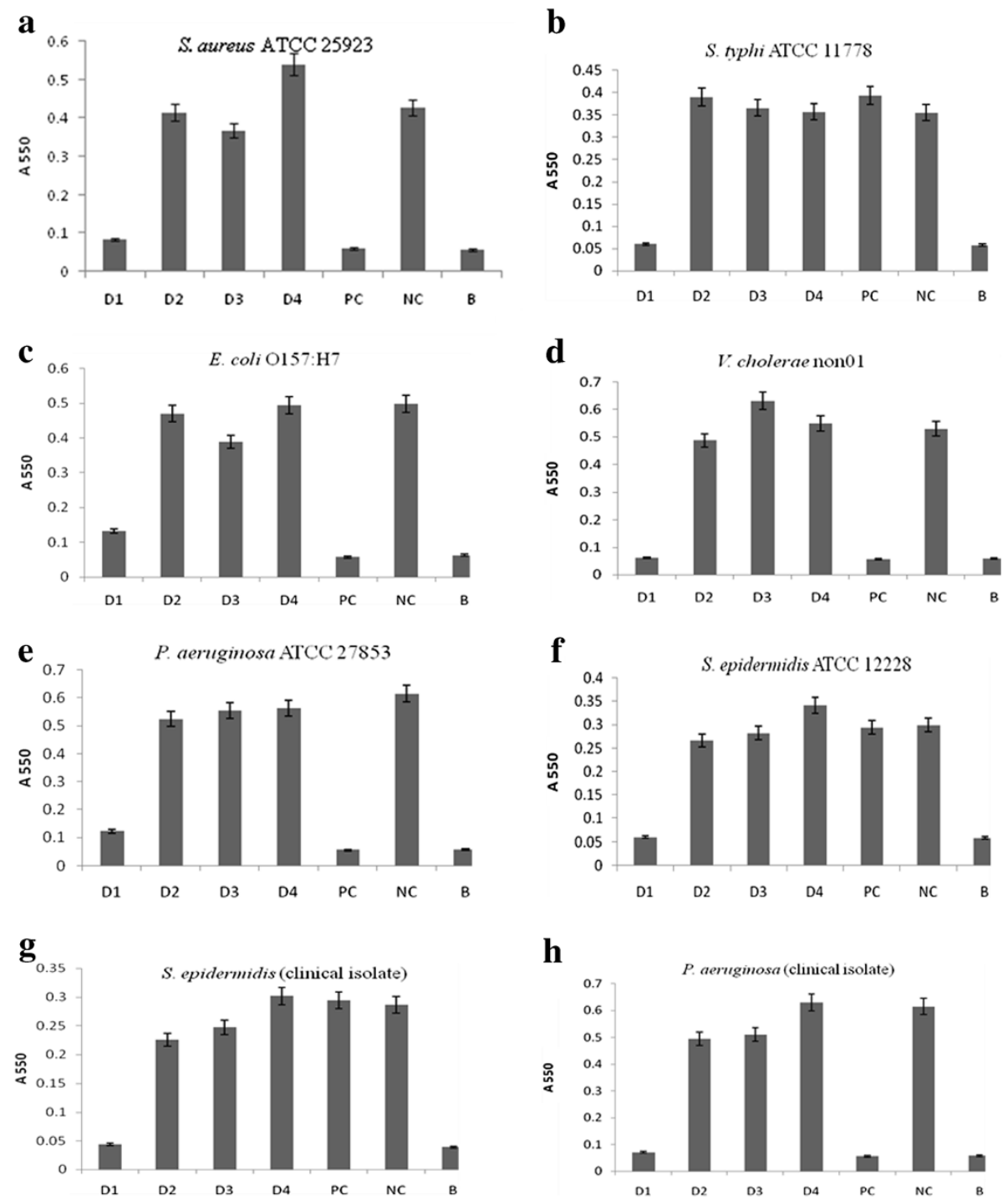

h
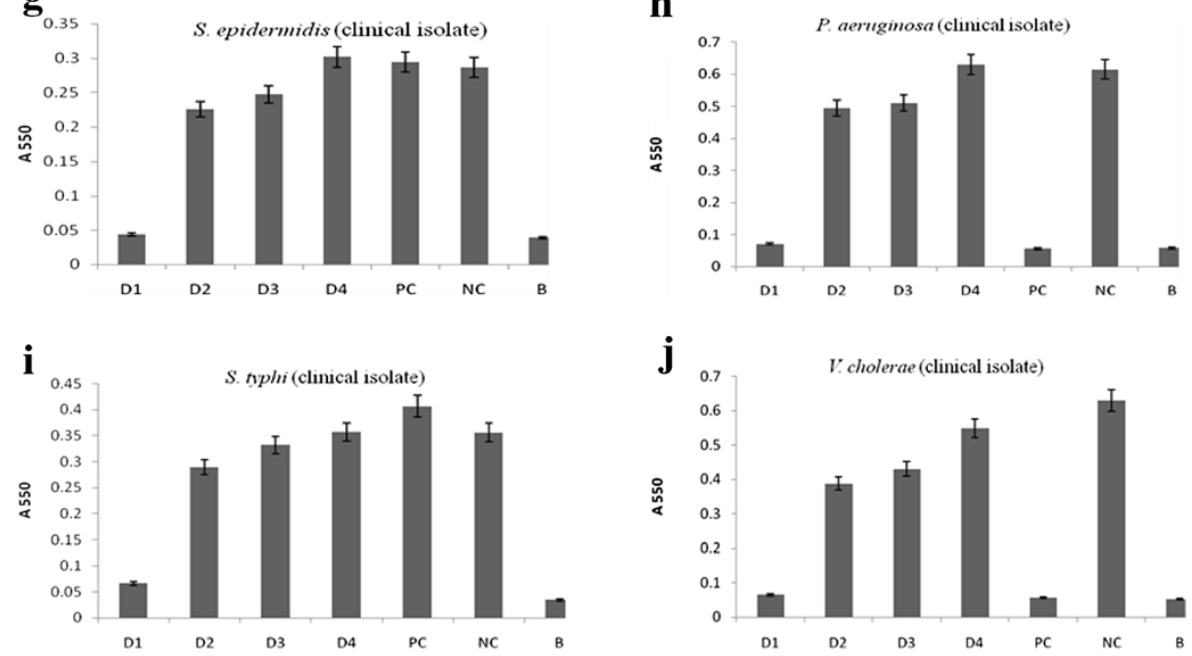

Figure 5 The antibacterial activity of the DEAE eluate fractions determined by the liquid growth inhibition assay. The growth inhibition test was made for $16 \mathrm{~h}$ with the final protein concentration $50 \mu \mathrm{g} / \mathrm{ml}$ of fraction D1, D2, D3, or D4. a, Staphylococcus aureus ATCC 25923; b. Salmonella typhi ATCC 11778; c, Escherichia coli 0157:H7; d, Vibrio cholerae non01; e, Pseudomonas aeruginosa ATCC 27853; f, Streptococcus epidermidis ATCC 12228; $\mathbf{g}$, Staphylococcus epidermidis clinical isolate; $\mathbf{h}$, Pseudomonas aeruginosa clinical isolate 1; i, Salmonella typhi clinical isolate $1 ; \mathbf{j}$, Vibrio cholerae clinical isolate 1; PC, with streptomycin $3 \mu \mathrm{g} / \mathrm{ml}$ in the final concentration; NC, without any of streptomycin and plasma fractions. 
the interior hydrophobic portions of the membranes and form pores in the membranes [15].

However, there was no report about the cytotoxicity of the compound administered to cells of a macrophage-like cell, RAW 264.7. The present data is the first report. The MTT assay, to assess the cytotoxicity of the Siamese crocodile plasma administered to cells of macrophage RAW 264.7, is an assay of metabolic competence based on assessment of mitochondrial performance by colorimetrical measuring of the conversion of yellow tetrazolium bromide (MTT) to the purple formazan derivative by mitochondrial succinate dehydrogenase in viable cells [25]. In the present study, the wells incubated with the crocodile plasma showed light yellow color, whereas the wells incubated as negative controls showed deep purple. From the MTT assay mentioned above, the Siamese crocodile plasma was not cytotoxic to the cells.

\section{Conclusions}

In summary, the crude and purified plasma from Crocodylus siamensis showed significantly antibacterial activity against pathogenic bacteria and reference strains by damage cell membrane of target bacterial. From the MTT assay, the Siamese crocodile plasma was not cytotoxic to the cells. On the basis of the results obtained above, the plasma extracted from Crocodylus siamensis was known to have a significant use as a clinical antimicrobial agent. So the subsequent studies are required to focus on the purification and characterization of the agent responsible for the antimicrobial activities including the anti-inflammatory activity.

\section{Competing interests}

The authors declare that they no competing interests.

\section{Authors' contributions}

JK and SP carried out the study and wrote the manuscript. SD, AD, YT, YY and ST supervised the work and the manuscript. YY contributed to the manuscript corrections. All authors read and approved the final manuscript.

\section{Acknowledgments}

The present study was supported by the Higher Education Research Promotion and National Research University Project of Thailand, Office of the Higher Education Commission, Khon Kaen University, Thailand. Finally, we wish to acknowledge the support of the Khon Kaen University Publication Clinic, Research and Technology Transfer Affairs, Khon Kaen University, for their assistance.

\section{Author details}

${ }^{1}$ Department of Biochemistry, Faculty of Science, Protein Proteomic Research Group, Khon Kaen University, Khon Kaen 40002, Thailand. 'Department of Microbiology, Faculty of liberal arts and science, Kasetsart University Kamphaeng saen Campus, Nakhon Pathom 73140, Thailand. ${ }^{3}$ Sriracha Moda Farm, Chon Buri 20110, Thailand. ${ }^{4}$ Faculty of Humanities and Social Sciences, Khon Kaen University, Khon Kaen, Thailand 40002. ${ }^{5}$ BIOTEC Culture Collection (BCC), National Center for Genetic Engineering and Biotechnology (BIOTEC), Pathumthani 12120, Thailand. ${ }^{6}$ JICA Senior Overseas Volunteer, Japan International Cooperation Agency (JICA), Shibuya-ku, Tokyo 151-8558, Japan. ${ }^{7}$ Shizuoka University, Suruga-ku, Shizuoka 422-8529, Japan.
Received: 1 May 2012 Accepted: 1 July 2012

Published: 30 July 2012

\section{References}

1. Waksman SA: What is an antibiotic or an antibiotic substance. Mycologia 1947, 39:565-69.

2. Steiner H, Hultmark D, Engstrom A, Bennich H, Boman HG: Sequence and specificity of two antibacterial proteins involved in insect immunity. Nature 1981, 292:246-48.

3. Ourth DD, Chung KT: Purification of antimicrobial factor from granules of channel catfish peripheral blood leucocytes. Biochem Biophys Res Commun 2004, 313:28-36.

4. Merchant ME, Roche C, Elsey RM, Prudhomme J: Antibacterial properties of serum from the American alligator (Alligator mississippiensis). Comp Biochem Physiol B Biochem Mol Biol 2003, 136:505-513.

5. Merchant ME, Roche CM, Thibodeaux D, Elsey RM: Identification of alternative pathway serum complement activity in the blood of the American alligator (Alligator mississippiensis). Comp Biochem Physiol B Biochem Mol Biol 2005, 141:281-288.

6. Merchant ME, Thibodeaux D, Loubser K, Elsey RM: Amoebacidal effects of serum from the American alligator (Alligator mississippiensis). J Parasitol 2004, 90:1480-83.

7. Merchant ME, Leger N, Jerkins E, Mills K, Pallansch MB, Paulman RL, Ptak RG: Broad spectrum antimicrobial activity of leukocyte extracts from the American alligator (Alligator mississippiensis). Vet Immunol Immunopathol 2006, 110:221-28.

8. Merchant ME, Pallansch M, Paulman RL, Wells JB, Nalca A, Ptak R: Antiviral activity of serum from the American alligator (Alligator mississippiensis). Antiviral Res 2005, 66:35-38.

9. Merchant ME, Mills K, Williams S, Kleckley F, Sims A, Elsey RM, Bushnell J: Effects of bacterial lipopolysachharide on peripheral leukocytes in the American alligator (Alligator mississippiensis). Vet Immunol Immunopathol 2006, 111:315-320.

10. Olson GA, Hessler JR, Faith RE: Technique for blood collection and intravascular infusion of reptiles. Lab Anim Sci 1975, 25:783-786.

11. Oren Z, Hong J, Shai Y: A comparative study on the structure and function of a cytolytic alpha-helical peptide and its antimicrobial beta-sheet diastereomer. Eur J Biochem 1999, 259:360-69.

12. Oren Z, Lerman JC, Gudmundsson GH, Agerberth B, Shai Y: Structure and organization of the human antimicrobial peptide LL-37 in phospholipid membranes: relevance to the molecular basis for its non-cell-selective activity. Biochem J 1999, 341(Pt3):501-13.

13. Preecharram $S$, Jearranaiprepame $P$, Daduang $S$, Temsiripong $Y$, Somdee $T$, Fukamizo T, Svasti J, Tomohiro A, Thammasirirak S: Isolation and Characterisation of Crocosin, an Antibacterial Compound from Crocodile (Crocodylus siamensis) Plasma. Ani Sci J 2010, 81:393-401.

14. Tiozzo E, Rocco G, Tossi A, Romeo D: Wide-spectrum antibiotic activity of synthetic, amphipathic peptides. Biochem Biophys Res Commun 1998, 249:202-06

15. Yeaman MR, Yount NY: Mechanisms of antimicrobial peptide action and resistance. Pharmacol Rev 2003, 55:27-5.

16. Zippel $\mathrm{KC}$, Lillywhite $\mathrm{HB}$, Mladinich $\mathrm{CR}$ : Anatomy of the crocodilian spinal vein. J Morphol 2003, 258:327-35

17. Hammerberg S, Marks MI, Weinmaster G: Reevaluation of the disk diffusion method for sulfonamide susceptibility testing of Neisseria meningitidis. Antimicrob Agents Chemother 1976, 10:869-71.

18. Charles H, Phillippe B: Strategies for the Isolation and Characterization of Antimicrobial Peptides of Invertebrates. In Antimicrobial peptide Protocols. Edited by Shafer WM. New Jersey: Humana Press; 1997:35-49.

19. Lau SK, Woo PC, Woo GK, Fung AM, Wong MK, Chan KM, Tam DM, Yuen KY: Eggerthella hongkongensis sp. nov. and Eggerthella sinensis sp. nov., two novel Eggerthella species, account for half of the cases of Eggerthella bacteremia. Diagn Microbiol Infect Dis 2004, 49:255-63.

20. Merchant ME, Britton A: Characterization of serum complement activity of saltwater (Crocodylus porosus) and freshwater (Crocodylus johnstoni) crocodiles. Comp Biochem Physiol A Mol Integr Physiol 2006 143:488-93

21. Ganz T, Lehrer Rl: Antimicrobial peptides in innate immunity. In Development of novel antimicrobial agents: emerging strategies. Edited by Lohner K. Norfolk, UK: Horizon Scientific, Wymondham; 2001:139-47. 
22. Arzese A, Skerlavaj B, Tomasinsig L, Gennaro R, Zanetti M: Antimicrobial activity of SMAP-29 against the Bacteroides fragilis group and clostridia. J Antimicrob Chemother 2003, 52:375-81.

23. Freer E, Pizarro CJ, Weintraub A, Bengoechea J, Moriyon I, Hultenby K, Gorvel J, Moreno E: The outer membrane of Brucella ovis shows increased permeability to hydrophobic probes and is more susceptible to cationic peptides than are the outer membranes of mutant rough Brucella abortus strains. Infect Immun 1999, 67:6181-86.

24. Henk WG, Todd WJ, Enright FM, Mitchell PS: The morphological effects of two antimicrobial peptides, hecate-1 and melittin, on Escherichia coli. Scanning Microsc 1995, 9:501-07.

25. Mosmann: Rapid colorimetric assay for cellular growth and survival: application to proliferation and cytotoxicity assays". J Of Immuno Methods 1983, 65(1-2):55-63.

doi:10.1186/1476-0711-11-22

Cite this article as: Kommanee et al:: Antibacterial activity of plasma

from crocodile (Crocodylus siamensis) against pathogenic bacteria.

Annals of Clinical Microbiology and Antimicrobials 2012 11:22.

\section{Submit your next manuscript to BioMed Central and take full advantage of:}

- Convenient online submission

- Thorough peer review

- No space constraints or color figure charges

- Immediate publication on acceptance

- Inclusion in PubMed, CAS, Scopus and Google Scholar

- Research which is freely available for redistribution 